\title{
Agnieszka Gajda, Krzysztof Grajewski, Piotr Uziębło, Anna Rytel- -Warzocha, Marcin Michał Wiszowaty, Partie polityczne w Polsce. Wybrane zagadnienia
}

\author{
Wydawnictwo Uniwersytetu Gdańskiego, Gdańsk 2017, 160 ss.
}

DOI: $10.19195 / 1643-0328.25 .14$

Niesłabnące zainteresowanie naukowe problematyką partii politycznych ma ważkie obiektywne uzasadnienie. Niezaprzeczalny jest bowiem wpływ partii politycznych na rzeczywistość polityczną, będącą w państwach demokratycznych przestrzenią rywalizacji konkurencyjnych koncepcji polityki, społeczeństwa, państwa i władzy. Należy przy tym zgodzić się z autorami omawianej publikacji, iż „nie ulega wątpliwości, że współczesne państwa demokratyczne nie mogą istnieć bez partii politycznych”, partie bowiem „w dużej mierze wyznaczają kierunek rozwoju państwa” (s. 7).

Monografia pt. Partie polityczne w Polsce. Wybrane zagadnienia jest dziełem badaczy reprezentujących Katedrę Prawa Konstytucyjnego i Instytucji Politycznych Wydziału Prawa i Administracji Uniwersytetu Gdańskiego. Opracowanie stanowi efekt badań prowadzonych głównie w 2016 r. Jak podkreślają sami autorzy,

badania te wpisały się w czas, w którym zmieniała się nie tylko polska scena polityczna i sposób funkcjonowania ugrupowań politycznych, ale także niektóre zasady funkcjonowania całego systemu politycznego, co w praktyce wiązało się ze wzmocnieniem faktycznej roli partyjnych organów decyzyjnych. Dlatego też autorzy mają nadzieję, że lektura książki pozwoli na zrozumienie choć w części istoty tych przeobrażeń (s. 9).

Autorzy doszli do prezentowanych ustaleń, wykorzystując metodę dogmatyczno-prawną oraz posiłkując się analizą funkcjonalną, metodami porównawczymi, historycznoprawnymi, analizą dokumentów partyjnych i analizą orzecznictwa. Nie powinna jednak zmylić czytelnika, najpewniej politologa, specyficzna prawnicza narracja; przeprowadzony przez autorów wywód ukazuje bowiem kierunki zmian politycznych i zarazem nieustającą słabość kultury politycznej w Polsce, objawiającą się m.in. politycznym cynizmem, wybiórczym i instrumentalnym traktowaniem demokratycznych zasad, a nawet, co pokazano na przykładach, wyraźnymi tendencjami niedemokratycznymi. Omawiana publikacja, napisana z pozycji konstytucyjnoprawnych, jawi się zatem jako pozycja interesująca również dla politologów, jako że analizy prawnicze i politologiczne wydają się komplementarne w kontekście celu naukowego, jakim jest weryfikacja faktycznej demokratyczności zarówno rozwiązań, które partie polityczne proponują, jak i tych, na których same się opierają (por. s. 11).

Piotr Uziębło omawia zagadnienie nabywania i utraty członkostwa w partiach politycznych oraz praw i obowiązków członków partii politycznych (s. 11-38). Badacz ten analizuje statuty przede wszystkim tych ugrupowań, które zarejestrowały swoje listy wyborcze w wyborach do Sejmu w 2015 r. Bada te dokumenty pod kątem demokratyczności wewnętrznych regulacji par- 
tyjnych w zakresie członkostwa oraz praw i obowiązków członkowskich. Autor m.in. zwraca uwagę, iż choć analizowane statuty nie budzą zasadniczych wątpliwości, to jednak wydają się zastanawiające, np. różnorodne formy regulowania kwestii lojalności wobec partii, które istotnie wpływają na charakter członkostwa w danej organizacji. Badacz ocenia, iż pomimo tego, że regulacje statutowe głównych polskich partii politycznych mieszczą się w demokratycznych granicach, to w niektórych, acz znaczących, przypadkach statuty „stwarzają najdalej idące możliwości ograniczania dyskusji wewnątrzpartyjnej” w imię interesów partii (s. 38).

Agnieszka Gajda podejmuje zagadnienie roli partii politycznych w wyborach (s. 39-58). Autorka wychodzi z założenia, iż partie „jako zorganizowane grupy obywateli [...] zmierzają do uzyskania określonych celów w drodze walki o władzę lub sprawowanie władzy" (s. 41), przy czym realizowanie przez nie funkcji wyborczej jest szczególnie istotne w kontekście demokratycznego systemu politycznego, albowiem właśnie poprzez rywalizację wyborczą partie „uzyskują wpływ na życie publiczne” (s. 43). Badaczka podkreśla, że „realizowana przez partie funkcja wyborcza jest jednym z czynników urzeczywistniających demokrację" (s. 57), niemniej — jak krytycznie ocenia - partie w Polsce zamiast skupiać się na merytorycznej rywalizacji i „pełnieniu roli ośrodków debat i dyskusji publicznych”, „dążą raczej do spotęgowania społecznego niezadowolenia” (s. 58), co — jak można dopowiedzieć — prowadzi do antagonizacji i polaryzacji politycznej.

Krzysztof Grajewski omawia kwestię statusu partii politycznych w ramach parlamentu (s. 59-94). Autor stwierdza, iż partie są „podmiotami (elementami) demokratycznych procedur rządzenia, co jednak nie oznacza, że - dosłownie rzecz ujmując - bezpośrednio rządzą państwem”. Są to podmioty polityki ściśle związane ze sprawowaniem władzy państwowej, a „ich rola polega na tym, że są one nie tylko jedną $\mathrm{z}$ form obywatelskiego prawa do zrzeszania się, ale przede wszystkim formą organizacji politycznej, która wywiera wpływ na sprawowanie władzy" (s. 63). Działalność partii w parlamencie nie jest oczywiście jedyną możliwą formą wpływania przez partie sposobami demokratycznymi na kierunki polityki, lecz ta akurat ma znaczenie zasadnicze. W tym kontekście Krzysztof Grajewski podejmuje również wątek jakości funkcjonowania polskiego ciała ustawodawczego po 2015 r. oraz wzajemnych relacji politycznych między partiami (zwłaszcza między rządzącymi a opozycją). Badacz ocenia:

Praktyka funkcjonowania parlamentu w ciągu ostatnich kilkunastu miesięcy może wskazywać na pojawienie się w praktyce ustrojowej polskiego ciała ustawodawczego pewnych elementów rządów autorytarnych. Chodzi głównie o podejmowanie przez partię rządzącą działań zmierzających do daleko idącej marginalizacji partii (frakcji) opozycyjnych w obu izbach parlamentu. Przejawia się to przede wszystkim $\mathrm{w}$ znacznym skracaniu regulaminowych terminów procedur parlamentarnych oraz w uniemożliwianiu przeprowadzenia rzeczywistej debaty nad procedowanymi projektami, co prowadzi do znacznego ograniczenia możliwości prezentowania własnych poglądów przez ugrupowania opozycyjne nie tylko na forum parlamentu, ale także społeczeństwu (s. 93).

Anna Rytel-Warzocha, odnosząc się do realizacji przez partie funkcji rządzenia (s. 95-112), zwraca uwagę, iz

głównymi aktorami sceny politycznej we współczesnym państwie demokratycznym są partie polityczne, które nie tylko wpisują się w zasadę pluralizmu politycznego, stanowiąc jej najważniejszy element, ale również są wyznacznikiem demokratycznego charakteru państwa (s. 95).

Funkcja rządzenia realizowana jest przez partie polityczne, najogólniej, poprzez sprawowanie władzy w drodze podejmowania decyzji politycznych oraz kierowania aparatem państwa. Partie polityczne w państwie demokratycznym, jak przekonuje autorka, uznać więc należy za podmiot „demokratycznych procedur rządzenia państwem” (s. 100), przy czym efektywność realizacji 
funkcji rządzenia przez partie polityczne zależy w głównej mierze od poszanowania przez nie owych procedur oraz takich zasad konstytucyjnych, jak np. zasada pluralizmu politycznego.

Marcin Michał Wiszowaty omawia alternatywne i komplementarne wobec partii politycznych, zinstytucjonalizowane formy artykulacji interesów w politycznym procesie decyzyjnym: lobbing, wysłuchanie publiczne, petycje, think-tanki oraz fundacje polityczne (s. 113-144). W swoim rozdziale autor przedstawia analizę ujawniającą różnorodność kanałów artykulacji interesów oraz wielość „instytucji pośredniczących” w procesie decyzyjnym.

Warto odnotować, iż wyraźną cechą poczynionych przez autorów analiz i rozważań prawno-politycznych jest odwołanie do problematyki pluralizmu politycznego. Autorzy uczynili z zasady pluralizmu politycznego ważne kryterium analityczne i interpretacyjne (tudzież ocenne). Należy zgodzić się z autorami, iż dochowanie przez partie polityczne wierności zasadzie pluralizmu politycznego i konsekwentne jej stosowanie w praktyce politycznej determinuje charakter całego systemu politycznego (s. 95). Zasada pluralizmu politycznego nie tylko bowiem pozwala realizować aktorom społecznym potrzebę zrzeszania się, lecz jeśli jest faktycznie stosowana, jest również gwarancją istnienia przedstawicielstwa, wielopartyjności, konkurencyjności wyborczej i ofert ideowo-programowych, a także wolności prezentowania poglądów i możliwości rywalizacji politycznej o sprawowanie władzy — jest więc fundamentalną regułą współczesnej demokracji (s. 39-40, 57-58, 59-61, 95, 111). Trudno sobie zatem wyobrazić, aby analiza funkcjonowania partii politycznych nie uwzględniała zasady pluralizmu politycznego, ponieważ bez niej wnioski na temat demokratyczności partii lub rządów przez nie sprawowanych miałyby istotne uchybienia.

Dobór materiałów, w oparciu o które przygotowano monografię, odzwierciedla sposób objaśniania interesujących autorów zagadnień, w którym zaakcentowano rolę formalnych (prawnych) mechanizmów funkcjonowania partii w strukturach systemu demokratycznego. Wykorzystano liczne akty prawne, orzeczenia, a także dokumenty partii politycznych. Wykaz literatury nie jest obszerny, ale koresponduje, po pierwsze, z zakresem zainteresowań dyscyplinarnych autorów oraz, po drugie, ze świadomie określonym, wąskim polem analizy.

Przygotowana przez prawników konstytucjonalistów z ośrodka gdańskiego publikacja pt. Partie polityczne w Polsce. Wybrane zagadnienia stanowi interesujące opracowanie. Autorski wybór zagadnień i problemów, uchwycenie obecnej dynamiki zmian w polskim życiu politycznym, a także zwięzła, syntetyczna prezentacja ustaleń pozwalają stwierdzić, iż omawiana monografia posiada nie tylko walor naukowy, lecz również jawi się jako użyteczna z perspektywy dydaktycznej.

Piotr Obacz

ORCID: 0000-0001-6397-2569 